To cite: R Naluwairo 'Improving the administration of justice by military courts in Africa: An appraisa of the jurisprudence of the African Commission on Human and Peoples' Rights' (2019) 19 African Human Rights Law Journal 43-61

\title{
Improving the administration of justice by military courts in Africa: An appraisal of the jurisprudence of the African Commission on Human and Peoples' Rights
}

\author{
Ronald Naluwairo* \\ Senior Lecturer, School of Law, Makerere University, Kampala, Uganda; Senior \\ Research Fellow, Advocates Coalition for Development and Environment \\ (ACODE) \\ https://orcid.org/0000-0002-8627-2597
}

\begin{abstract}
Summary
The African Commission on Human and Peoples' Rights was established to protect and promote human and peoples' rights on the African continent. This mandate extends to protecting and promoting human rights in the administration of justice by all organs that exercise judicial power, including military courts. In the execution of its mandate the African Commission has developed important jurisprudence on different aspects concerning the administration of justice by military courts. In this jurisprudence, the African Commission has expounded on what constitutes a violation of the African Charter on Human and Peoples' Rights and how military courts should administer justice in a manner that conforms to internationally-agreed standards, especially those relating to the right to a fair trial. Through desk review, the contribution appraises this jurisprudence. In analysing this jurisprudence, the article tries to draw a comparison, especially with the jurisprudence of the Human Rights Committee and other UN-established initiatives. It is argued that although the African Commission has done fairly well in interpreting the relevant provisions of the African Charter and in laying down principles and rules that should be followed by military courts in administering justice, there is still much the Commission can do to improve the administration of justice through military courts in Africa.
\end{abstract}

Key words: Africa; justice; right to a fair trial; military courts

* LLB (Hons) (Makerere) LLM (Cambridge) PhD (London); rnaluwairo@law.mak. ac.ug 


\section{Introduction}

Almost all African countries have military courts alongside civilian or ordinary courts. The main function of military courts is to administer justice with respect to military personnel and other persons subject to military law. This arrangement mainly is for purposes of the maintenance of military discipline which is considered critical for military efficiency. ${ }^{1}$ As some of the cases analysed in the article will show, it is also the case that some national governments establish special tribunals akin to military courts during war and civil disturbances to address justice needs arising in these situations. ${ }^{2}$ The administration of justice by military courts (hereafter used to include special courts) in Africa raises many concerns that can lead an informed and objective person to conclude that what many of these courts actually do is to dispense 'injustice' rather than 'justice', as the case should be. This situation mainly is because many military courts in African countries do not adhere to the internationally-accepted principles for the administration of justice, which makes it easy for these principles to be abused by the executive. For the most part, the internationally-accepted principles for the administration of justice are what is comprised in the right to a fair trial. The right to a fair trial is provided for in article 7 of the African Charter on Human and Peoples' Rights (African Charter) ${ }^{3}$ and article 14 of the International Covenant on Civil and Political Rights (ICCPR). ${ }^{4}$ Suffice to note that 53 of the 54 countries in Africa are party to the African Charter. The majority of African countries are also party to ICCPR.

This article examines the contribution of the African Commission on Human and Peoples' Rights (African Commission) in improving the administration of justice by military courts in Africa. This examination is done mainly through an analysis of the Commission's jurisprudence enunciated in its decisions on individual and interstate communications; its Concluding Observations and recommendations

1 See $M$ Gibson 'International human rights law and the administration of justice through military tribunals: Preserving utility while precluding impunity' (2008) 4 Journal of International and Relations Law 10. For an analysis of the validity of the existence of military justice as a separate system of justice in Uganda's context, see $R$ Naluwairo 'A reassessment of military justice as a separate system in the administration of justice: The case of Uganda' (2012) 18 East African Journal of Peace and Human Rights 136.

2 These tribunals are akin to military courts in a sense that they are often staffed and presided over by military personnel.

3 The African Charter on Human and Peoples' Rights was adopted on 27 June 1981 and entered into force on 21 October 1986. All countries in Africa are party to the Charter. The African Charter is Africa's major treaty for the protection and promotion of human and peoples' rights and fundamental freedoms on the African continent.

4 The International Covenant on Civil and Political Rights was adopted on 16 December 1966 and entered into force on 23 March 1976. It is the major international agreement for the protection and promotion of civil and political rights. All African states are party to ICCPR. 
on periodic reports of states; and principles, guidelines and resolutions. The most relevant principles, guidelines and resolutions considered in the article are the Principles and Guidelines on the Right to a Fair Trial and Legal Assistance in Africa; ${ }^{5}$ the Principles and Guidelines on Human and Peoples' Rights While Countering Terrorism in Africa; ${ }^{6}$ the Resolution on the Right to Fair Trial and Legal Assistance in Africa; ${ }^{7}$ the Resolution on the Right to Recourse and Fair Trial; $^{8}$ and the Resolution on the Respect and the Strengthening of the Independence of the Judiciary. ${ }^{9}$ Although examining the impact of the African Commission's jurisprudence on African countries' national military court systems and practice is important to fully appreciate the role of the Commission in improving the administration of justice by military courts, it is outside the scope of the article given the word limit and other limitations.

The article examines and summarises the African Commission's jurisprudence based on thematic issues. The article is divided into four parts. Before appraising the Commission's jurisprudence, it is important briefly to explore its establishment and functions. This is the main subject addressed in the next part.

\section{About the African Commission on Human and Peoples' Rights}

The African Commission is the major organ of the African Union (AU) charged with the responsibility of protecting and promoting human and peoples' rights on the African continent. It is established under article 30 of the African Charter. According to this provision, the Commission was established with the overall objective 'to promote human and peoples' rights and ensure their protection in Africa'. The African Commission is comprised of 11 members who, although

5 Adopted in 2003, http://www.achpr.org/instruments/principles-guidelines-rightfair-trial/ (accessed 30 May 2018).

6 Adopted by the African Commission during its 56th ordinary session in Banjul, The Gambia, 21 April-7 May 2015, http://www.achpr.org/files/instruments/ principles-guidelines-countering-terrorism/principles_and_guidelines_on_human_ and_peoples_rights_while_countering_terrorism_in_africa.pdf (accessed 3 June 2018).

7 Adopted by the African Commission at its 26th ordinary session held in November 1999 in Kigali, Rwanda, http://www.achpr.org/sessions/26th/resolutions/41/ (accessed 30 May 2018).

8 Adopted by the African Commission at its 11 th ordinary session, in Tunis, Tunisia, 2-9 March 1992, http://www.achpr.org/sessions/11th/resolutions/4/ (accessed 3 June 2018).

9 Adopted by the African Commission at its 19th ordinary session, Ouagadougou, Burkina Faso, 26 March-4 April 1996, http://www.achpr.org/sessions/19th/ resolutions/21/ (accessed 3 June 2018). 
elected by the Assembly of Heads of State and Government, serve in their personal capacity. ${ }^{10}$

The African Commission has four specific mandates. According to article 45 of the African Charter, the Commission is mandated:

(1) to promote human and peoples' rights and in particular:

(a) to collect documents, undertake studies and researches on African problems in the field of human and peoples' rights, organise seminars, symposia and conferences, disseminate information, encourage national and local institutions concerned with human and peoples' rights, and should the case arise, give its views or make recommendations to governments;

(b) to formulate and lay down principles and rules aimed at solving legal problems relating to human and peoples' rights and fundamental freedoms upon which African governments may base their legislations; and

(c) to cooperate with other African and international institutions concerned with the promotion and protection of human and peoples' rights;

(2) to ensure the protection of human and peoples' rights under conditions laid down by the present Charter;

(3) to interpret all the provisions of the present Charter at the request of a state party, an institution of the OAU or an African organisation recognised by the OAU; and

(4) to perform any other tasks which may be entrusted to it by the Assembly of Heads of State and Government.

To effectively carry out its functions the African Commission was given several powers. These include the power to receive and consider interstate communications alleging violations of the rights and freedoms provided for in the African Charter; ${ }^{11}$ to receive and consider individual communications alleging violations of the rights and freedoms provided for in the African Charter; ${ }^{12}$ and to receive and examine reports by state parties to the African Charter on the legislative and other measures taken in giving effect to the rights and freedoms provided for in the African Charter. ${ }^{13}$

In considering inter-state and individual communications, in examining the periodic state reports, and in its Principles, Guidelines and Resolutions, the African Commission has developed a body of jurisprudence on different aspects concerning the administration of justice by military courts. The next part appraises this jurisprudence and the contribution of the African Commission in improving the administration of justice by military courts in Africa.

10 See arts $31 \& 33$ of the African Charter.

11 Arts $47 \& 53$ African Charter.

12 Arts 55-58 African Charter.

13 Art 62 African Charter. 


\section{Jurisprudence of the African Commission regarding the administration of justice by military courts}

Without a doubt the major contribution by the African Commission in improving the administration of justice by military courts in Africa has been in the area of ensuring that they conform to and uphold the guarantees for the right to a fair trial as provided for in the African Charter and other international human rights instruments. In the African Charter, the guarantees of the right to a fair trial are provided for in articles 7 and 26. Article 7 provides:

(1) Every individual shall have the right to have his cause heard. This comprises:

(a) the right to an appeal to competent national organs against acts of violating his fundamental rights as recognised and guaranteed by conventions, laws, regulations and customs in force;

(b) the right to be presumed innocent until proved guilty by a competent court or tribunal;

(c) the right to defence, including the right to be defended by counsel of his choice; and

(d) the right to be tried within a reasonable time by an impartial court or tribunal.

(2) No one may be condemned for an act or omission which did not constitute a legally punishable offence at the time it was committed. No penalty may be inflicted for an offence for which no provision was made at the time it was committed. Punishment is personal and can be imposed only on the offender.

Article 26 of the African Charter enjoins state parties to the African Charter to ensure that their courts are independent. It provides that 'states parties to the present Charter shall have the duty to guarantee the independence of the courts'. In its Resolution on the Right to Fair Trial and Legal Assistance in Africa, ${ }^{14}$ the African Commission adopted the Dakar Declaration and Recommendations on the Right to a Fair Trial in Africa. In this Declaration the Commission emphasised that while exercising their functions military courts should respect fair trial standards. In its Principles and Guidelines on the Right to a Fair Trial and Legal Assistance in Africa, ${ }^{15}$ the African Commission restated this position. In section $\mathrm{L}(\mathrm{b})$ of these Principles and Guidelines the Commission emphasises that 'military courts are required to respect fair trial standards enunciated in the African Charter and in these guidelines'. In the Principles and Guidelines on Human and Peoples' Rights While Countering Terrorism in Africa the Commission reiterated this position. ${ }^{16}$

14 Resolution (n 7).

15 Principles and Guidelines (n 5).

16 Principles and Guidelines (n 6) Part IV (B). 
In a number of decisions on individual communications the African Commission has emphasised the fact that military courts should respect the guarantees of the right to a fair trial. Perhaps the most important case on this issue is Civil Liberties Organisation \& Others $v$ Nigeria. ${ }^{17}$ In this case the African Commission stressed that 'military tribunals must be subject to the same requirements of fairness, openness, justice, independence and due process as any other process'. The Commission's position that military and special courts should respect fair trial standards provided for in the African Charter is consistent with the jurisprudence of the Human Rights Committee. ${ }^{18}$ In its General Comment on the Right to a Fair Trial, the Human Rights Committee points out that the guarantees of the right to a fair trial provided for in article 14 of ICCPR apply 'to all courts and tribunals including military and other specialised courts'. ${ }^{19}$ In its jurisprudence the African Commission has attempted to expound on what amounts to the violation of fair trial rights in the context of the administration of justice by military courts and what needs to be done to ensure that military courts adhere to and respect the right to a fair trial. The following subsections summarise and appraise this jurisprudence. This is done based on thematic issues.

\subsection{Independence, competence and impartiality of military courts}

Although the African Charter explicitly provides for the right to a competent tribunal and the right to an impartial tribunal, ${ }^{20}$ it does not explicitly provide for the right to an independent tribunal. Nonetheless, article 26 of the African Charter obligates state parties to ensure that their courts and tribunals are independent. According to section $A(1)$ of the Principles and Guidelines on the Right to a Fair Trial and Legal Assistance in Africa ${ }^{21}$ it is provided, among others, that in determining any criminal charge against a person or in determining a person's rights and obligations, 'everyone shall be entitled to a fair and public hearing by a legally constituted competent, independent and impartial judicial body'. ${ }^{22}$ In section A(4) of these Principles and Guidelines the African Commission expounded on the essential requirements and other considerations for ensuring judicial independence.

17 (2001) AHRLR 75 (ACHPR 2001).

18 Just as the African Commission is charged with the responsibility of interpreting and monitoring the implementation of the African Charter, the Human Rights Committee is mandated to interpret and monitor the implementation of ICCPR.

19 See para 22 Human Rights Committee, General Comment 32, Article 14: Right to equality before courts and tribunals and to a fair trial, adopted during the 19th session of the Human Rights Committee, 9-27 July 2007, Geneva, Switzerland.

20 See arts 7(1)(b) and (d) of the African Charter.

21 Principles and Guidelines (n 5).

22 My emphasis. 
There are a number of cases involving military courts where the African Commission has addressed the question of what it takes for military courts to be independent, competent and impartial. In Marcel Wetsh'okonda Koso \& Others $v$ Democratic Republic of the Congo (Koso case) ${ }^{23}$ the military court in issue was comprised of five members, among whom only one was a trained jurist. The complainants requested the African Commission to declare, among others, that the mere fact of submitting their case to a court, the majority of whose members had no legal qualification whatsoever, constituted a blatant violation of article 26 of the African Charter. While observing that the 'independence of a court refers to the independence of the court visà-vis the executive', the Commission observed that as is the case with civil courts, in determining the independence of a military court, consideration should be given to 'the mode of designation of its members, the duration of their mandate, the existence of protection against external pressures and the issue of real or perceived independence'. ${ }^{24}$ This test for determining the independence of military courts is generally consistent with the international standards as expounded by the Human Rights Committee in General Comment 32 of 2007 and in the United Nations (UN) Basic Principles on the Independence of the Judiciary. According to the Human Rights Committee, the independence of courts refers

to the procedure and qualifications for the appointment of judges, and guarantees relating to their security of tenure ... the conditions governing promotion, transfer, suspension and cessation of their functions, and the actual independence of the judiciary from political interference by the executive branch and legislature. 25

In the Koso case the African Commission further stressed the fact that the ability of a court to offer justice depends on the competence and quality of its members. ${ }^{26}$ Citing its earlier decision in the case of Amnesty International \& Others $v$ Sudan, ${ }^{27}$ the Commission held that depriving courts of qualified staff to guarantee their impartiality constitutes a violation of article 26 of the African Charter which requires state parties to the Charter to guarantee the independence of courts. ${ }^{28}$ Accordingly, it asked the government of the Democratic Republic of the Congo (DRC) to introduce measures to guarantee the independence of tribunals. ${ }^{29}$ It is arguable that legally-qualified members of military courts are less likely to be influenced by external factors. They are more likely to adjudicate cases based on the law and facts, unlike members who are ignorant of the law.

(2008) AHRLR 93 (ACHPR 2008).

Koso (n 23) para 79.

General Comment 32 (n 19) para 19.

Koso (n 23) para 82.

(2000) AHRLR 297 (ACHPR 1999).

Koso (n 23) paras $82 \& 94$.

Koso para 96. 
In Law Office of Ghazi Suleiman $v$ Sudan (Law Office case) ${ }^{30}$ a number of civilians were tried by a military court established by presidential decree. This court was comprised of four members, three of whom were active military personnel. It was alleged, among others, that the military court was neither independent nor impartial as its members had been carefully chosen by the President. The African Commission observed that the composition of the military court alone was evidence of impartiality. ${ }^{31}$ It held that trying civilians in military courts presided over by active servicemen still under military regulations violated the right to a fair trial. This was largely because the military court was dominated by servicemen who were part and parcel of the executive. In this case, the African Commission also held that 'depriving the court of qualified staff to ensure its impartiality is detrimental to the right to have one's cause heard by competent organs'. ${ }^{32}$

In Constitutional Rights Project (in respect of Lekwot \& Others) $v$ Nigeria (Lekwot case) ${ }^{33}$ the Civil Disturbance (Special Tribunal) Act provided that the Special Tribunal in issue would consist of one judge and four members of the armed forces. The African Commission correctly found this composition to be in violation of the right to an impartial tribunal guaranteed in article $7(1)(d)$ of the African Charter. ${ }^{34}$ It was observed that the composition of the tribunal alone created 'the appearance, if not actual lack, of impartiality' ${ }^{35}$ Why did the African Commission so rule? This was largely because the tribunal did not appear to be impartial, as it was 'composed of persons belonging to the executive branch of government, the same branch that passed the Civil Disturbance Act' ${ }^{36}$ Moreover, as active service men the three members remained subject to the military chain of command. As Tshivhase correctly points out, the right to an impartial tribunal requires the absence of bias, actual or perceived. ${ }^{37}$ In this connection, the Human Rights Committee has stated: 38

The requirement of impartiality has two aspects. First, judges must not allow their judgment to be influenced by personal bias or prejudice, nor harbour preconceptions about the particular case before them, nor act in ways that improperly promote the interests of one of the parties to the detriment of the other. Second, the tribunal must also appear to a reasonable observer to be impartial.

30 (2003) AHRLR 134 (ACHPR 2003).

31 Law Office (n 30) para 64.

32 As above.

33 (2000) AHRLR 183 (ACHPR 1995).

34 Lekwot (n 33) para 14.

35 Lekwot para 14.

36 Lekwot para 13.

37 A Tshivhase 'Military courts in a democratic South Africa: An assessment of their independence' (2006) 6 New Zealand Armed Forces Law Review 121.

38 General Comment 32 (n 19) para 21. In Findlay $v$ The United Kingdom (1997) ECHR 8, the European Court of Human Rights expounded a similar test. 
Arguably, in the Lekwot case a reasonable and objective person could easily apprehend bias. The African Commission, therefore, was correct in holding the opinion it did.

From the jurisprudence summarised above four key factors emerge as critical to ensure that military courts are competent, independent and impartial. First, to achieve the independence of military courts it is critical to ensure that they are truly independent of the executive branch of government. This requirement is in line with the doctrine of separation of powers, which in this context demands a separation of judicial from executive functions and powers in order to have a proper system of checks and balances. Second, the critical aspects to consider in determining whether military courts are truly independent from the executive are the method of appointment/designation of their members; the length of their tenure; the existence of protection against external pressures; and the issue of real or perceived independence. Third, having legally-qualified persons as members of military courts is an important measure not only in guaranteeing the independence of military courts, but also their competence and impartiality. Fourth, in the particular context of trials of civilians in military courts staffed with and presided over by active servicemen, military courts cannot be considered impartial. This is essentially because active servicemen are part and parcel of the executive, and under their military codes they are obligated to respect the military chain of command. Where these military personnel are adequately insulated from obeying orders and the command influence when performing their judicial functions the threat of not being impartial can largely be reduced.

\subsection{Trials before military courts must be conducted in a manner that upholds the right to a presumption of innocence and should be public}

The right to presumption of innocence is provided for in article $7(1)(b)$ of the African Charter. This article provides that '[e]very individual shall have ... the right to be presumed innocent until proven guilty by a competent court or tribunal'. In the Media Rights Agenda $v$ Nigeria case $^{39}$ the African Commission held that the actions in issue were a violation of this provision, because prior to the setting up of the military tribunal there were intense pre-trial publicity events organised to make the general public believe that the arrested people had contrived a coup plot and, therefore, were guilty of treason. ${ }^{40}$ Similarly, in the Law Office case there was wide publicity concerning the suspects by state officials before and during the trial. This publicity was aimed at declaring the suspects guilty of the offences they were being tried for in the military court. The suspects were accused of a number of offences, including destabilising the constitutional system; 
inciting people to war; engaging in the war against the state; inciting opposition against the government; and abetting terrorism. The African Commission condemned the negative publicity before finding the suspects guilty by a competent court. ${ }^{41}$ It correctly held that such publicity violated the right to be presumed innocent as guaranteed in article 7(1)(b) of the African Charter. ${ }^{42}$

With respect to the right to a public hearing, this is not explicitly provided for in the African Charter. Nevertheless, invoking articles 60 and 61 of the African Charter ${ }^{43}$ the African Commission in a number of cases has held the right to a public hearing to be part and parcel of the right to a fair trial provided for in article 7. In the Media Rights Agenda case the military tribunal in issue excluded members of the public and the press from the trial. The complainant contended that this was a violation of the internationally-guaranteed right to a fair trial, in particular the right to a public hearing. Invoking articles 60 and 61 of the African Charter and article 14 of ICCPR, the Commission held that the exclusion of members of the public and the press from the trial amounted to a violation of the right to a public hearing. It observed that although the right to a public hearing was subject to exceptions, such as that a court or tribunal can exclude from the proceedings persons other than the parties thereto in the interests of defence, public safety and public order, it was not sufficient for Nigeria to present an omnibus statement in its defence to the effect that the right to a public hearing was subject to exceptions. Nigeria had to indicate specifically which of the permitted exceptions prompted it to exclude the public from the trial. ${ }^{44}$ Similarly, in the Civil Liberties case, where the communication alleged that except for the opening and closing ceremonies, the trial before the military court was conducted in camera, the African Commission found this to be a violation of the right to a public hearing, especially because Nigeria 'did not show that the holding of the proceedings in secret was within the exceptional circumstances contemplated under the African Charter'. ${ }^{45}$

In sum, from its jurisprudence highlighted above the African Commission points to the need for trials before military courts to be public, and in the case of exclusion of the public, for the military courts to give specific justifications within the permitted exceptions to the right to a public hearing. From the cases mentioned above, the African Commission also highlighted the great need for military and

41 Law Office (n 30) para 56.

42 As above.

43 In interpreting the provisions of the African Charter, arts 60 and 61 empower the African Commission to draw inspiration from international law and to take into consideration as subsidiary measures other general or special international conventions, customs generally accepted as law, general principles of law recognised by African states as well as legal precedents and doctrine.

44 Media Rights Agenda (n 39) paras 52-54.

45 Civil Liberties (n 17) para 39. 
other authorities to desist from prejudging cases before military courts and persuading members of the public to believe in the guilt of the accused before competent courts adjudge them so. All these factors are important in the quest to improve the administration of military justice by military courts in Africa.

\subsection{Military justice systems and military courts must guarantee and respect the right to defence}

The right to defence is provided for in article $7(1)(c)$ of the African Charter. This article provides that '[e]very individual shall have ... the right to defence, including the right to be defended by counsel of his choice'. The Constitutional Rights case involved a special tribunal composed of one judge and four members of the armed forces. It was alleged that during the trial counsel for the complainants were harassed and intimidated to the extent of being forced to withdraw from the proceedings. This situation notwithstanding, the tribunal continued with the hearing, found the accused guilty and sentenced them to death. This behaviour was held to be a violation of the defendants' right to defence as guaranteed in article $7(1)(c)$ of the African Charter. In the Civil Liberties case the African Commission held that the assignment of military counsel to the accused persons, despite their objections, and especially in criminal proceedings that carry the death sentence, was a breach of article 7(1)(c) of the African Charter. ${ }^{46}$ The Commission observed that the purpose of guaranteeing the accused's right to counsel of their own choice was to ensure that the accused has confidence in his defence counsel. ${ }^{47}$ It rightly argued that even in cases where the accused is unable to afford legal counsel and is to be represented by counsel provided at the expense of the state, he or she should be able to choose from a list of his or her preferred independent counsel answerable only to him or her. ${ }^{48}$

In the Law Office case a military court delivered a judgment of which the purpose was to prevent the lawyers chosen by the accused from appearing in the military court. Citing its earlier decision in Amnesty International \& Others $v$ Sudan ${ }^{49}$ (where the African Commission stressed the fact that to recognise that a court has the right to veto the accused's choice of counsel amounts to an unacceptable violation of the right to defence), ${ }^{50}$ the Commission held that refusing the victims the right to be represented by a lawyer of their choice (Ghazi Suleiman) amounted to a violation of article $7(1)(c)$ of the African Charter. In Malawi African Association \& Others $v$

46 Civil Liberties para 31.

47 Civil Liberties para 28.

48 Civil Liberties para 29.

49 (2000) AHRLR 297 (ACHPR 1999).

50 Amnesty International ( $\mathrm{n} 49$ ) para 59. 
Mauritania $^{51}$ the African Commission argued that the right to defence included the right to understand the charges being brought against one. In one of the trials under issue, only three out of the 21 accused persons were fluent in the Arabic language. Arabic was the language used during the trial. It found Mauritania to be in breach of article $7(1)(c)$ of the African Charter as 18 of the accused 'did not have the right to defend themselves'.

From the African Commission's jurisprudence above the following points are important to improve the administration of justice by military courts from the perspective of the right to defence. First, military courts must respect accused persons' choice of counsel. Conversely, military courts and military authorities should never impose counsel on accused persons. Even when the state is meeting the expenses of defense counsel, persons appearing before military courts should be allowed to choose from a list of defense counsel. Third, members of the military courts must act with respect towards defense counsel. They should not engage in acts aimed at intimidating or harassing defence counsel. Fourth, military courts must ensure that accused persons appearing before them understand the charges against them.

\subsection{Military laws and other legislations should never foreclose the right of appeal from decisions of military courts}

Article 7(1)(a) of the African Charter provides for the right of appeal. This article provides that '[e]very individual shall have ... the right to an appeal to competent national organs against acts of violating his fundamental rights as recognised and guaranteed by conventions, laws, regulations and customs in force'. There are numerous decisions where the African Commission has consistently held that foreclosing appeals from decisions of military and special courts is a violation of the right to appeal as guaranteed in the African Charter. In the Media Rights Agenda case ${ }^{52}$ Nigeria was held to be in violation of the right of appeal because by law, decisions of the special military tribunal that tried and convicted Malaolu were not subject to appeal. According to the Treason and Other Offences (Special Military Tribunal) Decree 1 of 1986, decisions of the Special Military Tribunal were subject only to confirmation by the Provisional Ruling Council.

In the Civil Liberties case, the African Commission held that the foreclosure of any avenue of appeal to competent national organs in a criminal case involving the death penalty was a clear violation of article $7(1)(a)$ of the African Charter. ${ }^{53}$ In this case, as was the situation in Media Rights Agenda, the decision of the tribunal was not subject to appeal, but to confirmation by the Provisional Ruling Council, the members of which were exclusively members of the 
armed forces. Similarly, in the Law Office case the African Commission found Sudan to be in violation of article 7(1)(a) of the African Charter on the basis that the decisions of the military court in issue were not subject to appeal. ${ }^{54}$ The Commission rightly emphasised the fact that preventing the submission of an appeal to competent national courts increased the risk of not remedying the procedural defects that could have occurred during the hearing. 55

\subsection{The jurisdiction of military courts should be confined to trials of military personnel accused of committing military offences}

An awkward question that the African Commission has addressed concerning the administration of justice by military courts is the issue of jurisdiction. In terms of jurisdiction over subject matter, the Commission's position is that military courts should have jurisdiction over only military and not over civil offences. With respect to jurisdiction over persons its position is that military courts should have jurisdiction over only military personnel and not over civilians. In its Dakar Declaration and Recommendations on the Right to a Fair Trial in Africa, the Commission stated that '[t]he purpose of military courts is to determine offences of a pure[ly] military nature committed by military personnel ... they should not in any circumstances whatsoever have jurisdiction over civilians' ${ }^{56}$

In similar terms, in its Principles and Guidelines on the Right to a Fair Trial and Legal Assistance in Africa, ${ }^{57}$ the African Commission reiterated that '[t]he only purpose of military courts shall be to determine offences of a purely military nature committed by military personnel' ${ }^{58}$ To this effect the Commission stressed that '[m]ilitary courts should not in any circumstances whatsoever have jurisdiction over civilians'. ${ }^{59}$ This position has been upheld also in a number of the Commission's decisions on individual communications and in some Concluding Observations and Recommendations on periodic state reports. In the Media Rights case, for instance, the African Commission held that the arraignment, trial and conviction of Malalou - a civilian by a special military tribunal, presided over by a serving military officer, was a violation of the principles of the right to a fair trial guaranteed by article 7 of the African Charter. ${ }^{60}$ The Commission also found the trial to be in contravention of Principle 5 of the UN Basic Principles on the Independence of the Judiciary. ${ }^{61}$ Similarly, in the

54 Law Office (n 30) para 53.

55 As above.

56 Resolution (n 7).

57 Principles and Guidelines (n 5).

58 See sec L(a).

59 As above.

60 Media Rights Agenda (n 39) para 61.

61 Media Rights Agenda para 64. Principle 5 of the UN Basic Principles on the Independence of the Judiciary provides, inter alia, that '[e]veryone shall have a right to be tried by ordinary courts'. 
Koso case the African Commission found that the establishment of the military court in question, of which the jurisdiction extended to hearing civil acts perpetrated by civilians, was a blatant violation of article 7 of the African Charter. ${ }^{62}$ In this case, civilians and soldiers accused of the theft of drums of fuel were tried together in a military court.

In its Concluding Observations and Recommendations on Uganda's third periodic report the African Commission expressed concern that the state had not introduced measures to 'comply with article 7 of the African Charter and, in particular, the 2001 Principles and Guidelines on Fair Trial and Legal Assistance in Africa, as they relate to the prohibition of trials of civilians by military tribunals' as it had earlier recommended in the Concluding Observations and Recommendations on the country's second periodic report. ${ }^{63}$ It once again urged Uganda to introduce legal measures to prohibit the trial of civilians by military courts. ${ }^{64}$

With particular reference to special tribunals the African Commission has been emphatic that their jurisdiction should not include trying offences over which ordinary courts have jurisdiction. ${ }^{65}$ In the Media Rights case the Commission held that the setting up of the special military tribunal and clothing it with jurisdiction to try treason and other related offences (which offences were recognised by Nigerian law as falling within the jurisdiction of the regular courts) was unacceptable as it infringed on the independence of the judiciary. ${ }^{66}$

Besides infringing on the independence of the judiciary the practice of giving special tribunals and military courts the jurisdiction that belongs to ordinary courts undermines the authority of ordinary courts which they should enjoy in any country that cherishes democracy and the rule of law. In Civil Liberties Organisation $v$ Nigeria $^{67}$ the Treason and Other Offences (Special Military Tribunal) Act contained ouster clauses that removed the jurisdiction of civil courts to try persons accused of treason-related offences. The special military tribunal in issue was established under this Act. It was composed of five serving military personnel. Thirteen civilians were tried by this tribunal, which found them guilty of being accessories to

62 See Koso (n 23) para 95.

63 Concluding Observations of the African Commission on the 3rd periodic report of the Republic of Uganda, adopted during the 45th ordinary session of the African Commission, Banjul, The Gambia, 13-27 May 2009. The Commission's Concluding Observations and Recommendations on Uganda's 2nd periodic report were adopted at the Commission's 40th ordinary session, 15-29 November 2006.

64 For an analysis of the reasons and constitutionality of the trial of civilians in military courts in Uganda, see R Naluwairo 'The trial of civilians in Uganda's military courts: Interrogating the reasons and constitutionality' (2013) 19 East African Journal of Peace and Human Rights 383.

65 See sec L(b) of the Principles and Guidelines on the Right to a Fair Trial (n 4).

66 Media Rights Agenda (n 39) para 63.

67 (2000) AHRLR 243 (ACHPR 1999). 
treason. They were sentenced to life imprisonment. While holding that ouster clauses were a violation of article 7 of the African Charter, the African Commission urged Nigeria to 'end the practice of removing entire areas of law from the jurisdiction of the ordinary courts'.68 It correctly argued that the practice of setting up a parallel system of justice administration was not acceptable as it undermined the civil court system. ${ }^{69}$ The African Commission correctly argued that such a practice also created the possibility of an unequal application of the law. ${ }^{70}$ The Commission observed that if the ordinary courts were overburdened by numerous cases as a result of the breakdown of law and order, it was better for the Nigerian government to allocate more resources than to create a parallel court system. ${ }^{71}$ In the Law Office case the Commission reiterated its position that military courts should not deal with offences that are under the purview of ordinary courts. $^{72}$

The African Commission's position that military courts should not have jurisdiction over civilians and offences that fall within the jurisdiction of ordinary courts is partly consistent with the UN Basic Principles on the Independence of the Judiciary. According to these principles, '[e]veryone has the right to be tried by ordinary courts or tribunals using established legal procedures' ${ }^{73}$ The Principles emphasise that courts that do not use the duly-established procedures of the legal process should not be created to displace the jurisdiction belonging to civil courts. ${ }^{74}$

The African Commission's position that military courts should not have jurisdiction over civilians is consistent with the Draft Basic Principles Governing the Administration of Justice through Military Tribunals (commonly referred to as the Decaux Principles). ${ }^{75}$ These Principles provide that '[m]ilitary courts should, in principle, have no jurisdiction to try civilians' ${ }^{76}$ It is stressed that '[i]n all circumstances, the state shall ensure that civilians accused of a criminal offence of any nature are tried by civilian courts'. ${ }^{77}$ This position is also in line with some expert groups' opinions. ${ }^{78}$ However, it is worth noting that the

68 Civil Liberties (n 67) para 17.

69 Civil Liberties para 23.

70 As above.

71 Civil Liberties paras 18 \& 23.

72 Law Office (n 30) para 65.

73 Law Office para.5

74 As above.

75 Draft Principles Governing the Administration of Justice Through Military Tribunals, UN Doc E/CN.4/2006/58 4 (2006), Report submitted by the Special Rapporteur of the Sub-Commission on the Promotion and Protection of Human Rights, http://hrlibrary.umn.edu/instree/DecauxPrinciples.html (accessed 12 June 2018). For a critique of the Decaux Principles, see Gibson (n 1).

76 See Principle 5.

77 As above.

78 See, eg, UN Human Rights Council Report of the Working Group on Arbitrary Detention, 30 June 2014, A/HRC/27/48 para 69(a), http://www.refworld.org/ docid/53eb29a04.html (accessed 12 June 2018). 
African Commission's position on the issue of military courts and civilians is inconsistent with its earlier decision. In the Civil Liberties case, one civilian and five soldiers were arraigned, tried, convicted and sentenced to death by a military court in Nigeria. The African Commission refused to hold the Nigerian state to be in breach of article $7(1)(d)$ of the African Charter based on the mere fact that a civilian had been tried by a military court chaired by a military persona. ${ }^{79}$ It argued that the accused civilian was part of a common conspiracy and that it was reasonable to charge him with his military co-accused in the same military court. ${ }^{80}$ In other words, the Commission found no issue with a civilian being tried in a military court. In this case the Commission observed that military tribunals were not negated by the mere fact of being presided over by military officers. $^{81}$ It emphasised that what is critical is whether the military tribunal processes are fair, just and impartial. ${ }^{82}$

A question may be posed at this point: Why did the African Commission depart from its decision in the Civil Liberties case now rigidly to insist that military courts should not have jurisdiction over civilians? First, since the existence of military courts in many countries is largely justified by the need to maintain military discipline, it makes sense to restrict their jurisdiction to only acts and omissions and only committed by those individuals whose acts and omissions can negatively impact military discipline. For the most part these acts and omissions are military offences and the individuals whose acts and omissions mainly impact on military discipline are serving military personnel. Second, it is arguable that the other reason why the African Commission does not accept the trial of civilians by military courts is because of their bad track record as far as respecting the right to a fair trial and other human rights is concerned. As some of the cases analysed in the article have demonstrated, incidents of violations of fair trial rights by military courts in African countries are numerous. These range from staffing military courts with legallyincompetent serving military personnel; holding trials in camera; adjudging accused persons guilty until proven otherwise; denying accused persons their right to counsel of their choice; and foreclosing possibilities of appeal from their decisions. In many cases the military courts also employ arbitrary procedures. In some countries, such as Uganda, for instance during Amin's regime, military courts could even conduct trials in the absence of accused persons, who would simply be informed of the court's decision and sentence. ${ }^{83}$

79 Art 7(1)(d) of the African Charter provides that '[e]very individual shall have the right to have his cause heard. This comprises ... (d) the right to be tried within a reasonable time by an impartial court or tribunal.'

80 Civil Liberties (n 67) para 25.

81 Civil Liberties para 27.

82 As above.

83 Amnesty International Human Rights in Uganda Report (1978) 4. 
However, the view of the African Commission that military courts should not have jurisdiction over civilians in whatever circumstances is problematic with respect to some international human rights treaties; in particular ICCPR and the Geneva Conventions. With respect to ICCPR, the Human Rights Committee has stated that the treaty does not prohibit the trial of civilians in military courts. ${ }^{84}$ However, it has emphasised that the trials of civilians in military courts should be exceptions. According to the Committee the trial of civilians in military courts should be limited to cases where such trials are 'necessary and justified by objective and serious reasons, and where with regard to the specific class of individuals and offences at issue, the regular civilian courts are unable to undertake the trials' ${ }^{85}$ This majority view of the Human Rights Committee that ICCPR does not prohibit trials of civilians in military courts, however, is contested by some members of the Committee. In Akwanga $v$ Cameroon $^{86} \mathrm{Mr}$ Fabian Omar Salvioli disagreed with the Committee's position. In his view, if it was the intention of the drafters of ICCPR to allow the trial of civilians by military courts in certain circumstances, they would have explicitly stated so. ${ }^{87}$ In Musaev v Uzbekistan ${ }^{88}$ two members of the Human Rights Committee (Mr Fabián Omar Salvioli and Mr Rafael Rivas Posada) partially dissented with the Committee's position. They argued that while it is true that ICCPR does not prohibit the trial of civilians in military courts, there also is nothing to suggest that military justice can be applied to civilian jurisdiction. They called for a review of the Committee's position which considers the trial of civilians in military courts to be compatible with ICCPR.

With respect to the Geneva Conventions, Geneva Convention III Relative to the Treatment of Prisoners of War of 12 August 1949 allows for trials of prisoners by military courts. Under article 84, it is provided that prisoners of war are to be tried only by military courts, unless the laws of the detaining power expressly permit civil courts to try a member of the armed forces of the detaining power in respect of the particular offence alleged to have been committed by the prisoner of war. According to this provision civilians may be accorded the status of prisoners of war under article 4 of Geneva Convention III if they are (a) accompanying the armed forces of a belligerent; (b) crew members of merchant ships or civil aircraft flagged or registered to a belligerent; (c) parties to a levée en masse; or (d) former members of the armed forces who have been interned by the opposing belligerents for security reasons.

Geneva Convention IV Relative to the Protection of Civilian Persons in Time of War of 12 August 1949 also allows for the trial of civilians

84 General Comment 32 (n 19) para 22.

85 As above. See also Madani v Algeria CCPR/C/89/D/1172/2003 (2007).

86 Akwanga $v$ Cameroon CCPR/C/101/D/1813/2008 (2011).

87 Akwanga (n 86) para 4.

88 Musaev v Uzbekistan CCPR/C/104/D/1914, 1915 \&1916/2009. 
by military courts. Under articles 64 and 66 of this Convention, during occupation it is allowed for the occupying power to subject the civilian population of the occupied territory to its 'properly constituted, non-political military courts'. However, this is only acceptable when the military courts are based in the occupied country.

In sum, considering that international humanitarian law explicitly allows for the trial of civilians by military courts in certain circumstances and given the need to ensure accountability by retired military personnel for crimes committed while still serving, the better view is that expressed in the Decaux Principles: the Yale Draft Principles for Governing Administration of Justice through Military Tribunals. ${ }^{89}$ The Yale Draft provides:

Military courts have no jurisdiction to try civilians except where there are very exceptional circumstances and compelling reasons based on a clear and foreseeable legal basis, made as a matter of record, justifying such a military trial. Those circumstances only exist, where

(a) such a trial is explicitly permitted or required by international humanitarian law;

(b) the civilian is serving with or accompanying a force deployed outside the territory of the sending state and there is no appropriate civilian court available; or

(c) the civilian who is no longer subject to military law is to be tried in respect of an offence allegedly committed while he or she was serving as a uniformed member of the armed forces or he or she was a civilian subject to military law under paragraph (b).

\section{Conclusion}

This article has summarised and appraised the jurisprudence of the African Commission concerning the administration of justice through military courts. Most of the Commission's jurisprudence in this area is concentrated on the jurisdiction of military courts, acts and omissions of military courts that amount to violations of the African Charter, and what can be done to ensure that the administration of justice through military courts complies with international standards of administration of justice. From the above analysis it is fair to conclude that the African Commission has done relatively well, especially with respect to articulating principles, rules and making recommendations aimed at improving the administration of justice by military courts in Africa.

What is contestable is whether these principles, rules and recommendations have translated into actual legal, policy and practice reforms in the way in which military courts in the different

89 The Yale Draft is an outcome of the workshop of experts on military law held at Yale Law School, Yale University, New Haven, USA, 23-24 March 2018. The author of this article was among the experts that participated in this workshop. 
African countries administer justice. For instance, as highlighted earlier, in its 2009 Concluding Observations and Recommendations on Uganda's third periodic report the African Commission expressed concern that the government had not introduced measures to prohibit the trial of civilians in military courts as it had recommended in 2006. To date (13 years since the African Commission first made this recommendation) Uganda's military courts retain jurisdiction over many categories of civilians beyond what is acceptable in international human rights law. Consequently, in order to fully appreciate the contribution by the African Commission in improving the administration of justice by military courts in Africa, the impact of its jurisprudence on national military court systems and practices needs to be studied in detail.

Also, given its mandate with respect to the promotion and protection of human rights on the African continent several things remain that the African Commission can do to improve the way in which military courts administer justice in the different African countries. First, there is a need for the Commission to undertake or commission studies on different thematic issues concerning military courts and the administration of justice. Second, the Commission should consider organising a high-level multi-stakeholder symposium or conference on the issue of administration of justice through military courts in Africa. Third, although it is appreciated that decisions of the African Commission are not binding, it should at least inquire into and attempt to find out from the respective states why its decisions and recommendations aimed at improving the administration of military justice by military tribunals are not enforced or implemented. 